\title{
管理栄養士の立場から特定保健指導の現状
}

\author{
徳永 佐枝子 \\ (中部労㷋病院 栄養管理室長)
}

\section{The assessment of specific health guidance from the position of a dietitian}

\author{
Saeko Tokunaga \\ Japan Labour Health and Welfare Organization Chubu Rousai Hospital, \\ 1-10-6 Koumei Minato-ku Nagoya 455-8530 \\ 干455-8530 名古屋市港区港明 1-10-6
}

\begin{abstract}
In recent years, although lifestyle-related diseases have continued to increase, escalation in medical-treatment expenses persists. To create a society of vital, peaceful, and healthy people, the Ministry of Health, Labour, and Welfare made a policy called "healthy Japan 21", making the health of the nation a priority. However, an intermediate evaluation of lifestyle-related diseases did not show a trend toward improvement that was intended by the policy. Therefore, in 2008, a new health check-up, which was substituted for the conventional medical check-up and health guidance, was instituted to prevent metabolic syndromes. The new health guidance, which is conducted by a doctor, a national registered dietitian, and a public-health nurse consults a subject dividing into three different categories: positive support, incentive support, and offering information. The Aichi dietitian society supports the training for a national registered dietitian and performs specific health guidance under the management of the Aichi nutrient care station. However, at present, there is little hope for patients to benefit from the health guidance because most do not cooperate. It is necessary that the person in charge working on a subject to effectively employ the specific health guidance. We believe that the administration and private enterprise should unite to make the new health check-up system more effective.
\end{abstract}

\section{1.はじめに}

近年, 急速な人口の高齢化や生活様式の変化に伴い, 疾病構造も変化し生活習慣病と呼ばれる虚血性心疾患・ 脳血管疾患・糖尿病等が増加してきた。国は, 平成12年 より，全ての国民が健やかで心豊かに生活できる活力あ る社会とするため「21世紀における国民健康づくり運動 （健康日本21）」を策定した。健康日本21は，健康寿命の 延伸等を実現するため, 平成 22 年をめどとし健康づくり の具体的な目標を掲げて国民が一体となって健康づくり の意識向上及び取り組みを進めることを目的とした。し かし, 中間評価において, 糖尿病有病者数・予備軍の増
加, 肥満者の増加（特に20～60歳代男性）, 野菜摂取量 の不足, 日常生活における歩数の減少と改善どころか悪 化している傾向が明らかになった。このままでは, 国民 の健康づくり運動には不十分であるとの考えから, 生活 習慣病対策の充実・強化を図ることとなった。国は, 今 までの健診・保健指導を見直し平成 20 年度から，『高齢 者の医療の確保に関する法律』および健康増進法に基づ き，40〜 74歳の被保険者 · 被扶養者に内藏脂肪症候群 (メタボリックシンドローム) の概念を取り入れた特定 健診 ·保健指導を導入した。今回大きな特徵は, 医師 · 保健師 ·管理栄養士を中心として, 健診結果に基づき階 層化された健診受診者に保健指導を実施し, 改善すべき 
生活習慣を明らかにし, 病気になるリスクを減少させ医 療費増大に歯止めをかけることである。医療保健者は, 特定健診・保健指導を行うことが義務化され，糖尿病な ぞの生活習慣病およびその予備軍を $25 \%$ 減少させること を目指すこととなった。この取り組みに対し, 日本栄養 土会は，保健指導で結果を出せる管理栄養士育成に力を 注ぎ, 全国各都道県で特定保健指導者研修を行いこの事 業に対して積極的に取り組んでいる。平成 20 年 4 月より, 始まった特定健診・保健指導の普及や管理栄養士の活動 に対しどのような課題や問題点があるかを愛知県の現状 を中心に述べる。

\section{2. これからの特定健診 ·保健指導とは}

今回の特定健診 ·保健指導の大きな特徵の一つは, 内 蔵脂肪症候群（メタボリックシンドローム）に焦点を当 てたことである。内臓脂肪が蓄積されると, 脂肪細胞か ら多彩な生理活性物質が分泌されることが分かっている。
特に内蔵脂肪がたまると活性化される $\mathrm{TNF}-\alpha$, アンジ オテンシノーゲン, PA-1が分泌される反面, よい生 理活性物質と言われるアディポネクチンが分泌減少した り働きが抑制されることにより，代謝の乱れが起こり高 血糖, 脂質異常, 高血圧を合併する状態へと進行する。 今回は, 内臓脂肪の量を腹囲で判定し, 内臓脂肪症候群 (メタボリックシンドローム) の該当者・予備軍を早く 見つけ減少させることを大きな目標としている。基本的 健診項目として, 質問項目・身体計測（身長，体重， BMI, 腹囲), 理学的検査 (身体診察), 血圧測定, 血 液化学検査 (中性脂肪, HDL コレステロール, LDL コ レステロール, ) 肝機能検査 (AST, ALT, $\gamma$-GTP), 血糖検査（空腹時血糖又は $\mathrm{HbA} 1 \mathrm{c}$ 検査）, 尿検査（尿 糖, 尿蛋白) である。判定基準はメタボリックシンドロー 厶, 糖尿病, 高血圧症, 脂質異常症などの関係する学会 のガイドラインに沿っている。また, 詳細な健診項目と して, 心電図検査, 眼底検査, 貧血検査は医師の判断で

\section{表 1 内臓脂肪型肥満に着目した生活習慣病予防のための健診・保健指導の基本的な} 考え方

\begin{tabular}{|c|c|c|c|}
\hline & これまでの健診·保健指導 & \multirow[b]{2}{*}{$\begin{array}{l}\text { 課最 } \\
\text { 題 新 } \\
\text { 抽 } \\
\text { 出 科 } \\
\text { 学 } \\
\text { た 的 } \\
\text { め知 } \\
\text { 識 } \\
\text { 分 と, } \\
\text { 析 }\end{array}$} & これからの健診·保健指導 \\
\hline $\begin{array}{c}\text { 関健 } \\
\text { 係診 } \\
\text { 保 } \\
\text { 健 } \\
\text { 指 } \\
\text { 導 } \\
\text { の }\end{array}$ & 健診に付加した保健指導 & & $\begin{array}{l}\text { 内臓脂肪型肥満に着目した生活習 } \\
\text { 慣病予防のための保健指導を必要 } \\
\text { とする者を抽出する健診 }\end{array}$ \\
\hline $\begin{array}{l}\text { 特 } \\
\text { 徵 }\end{array}$ & $\begin{array}{l}\text { プロセス（過程）重視の保健 } \\
\text { 指導 }\end{array}$ & \multirow{4}{*}{ 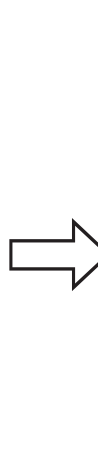 } & 結果を出す保健指導 \\
\hline $\begin{array}{l}\text { 目 } \\
\text { 的 }\end{array}$ & $\begin{array}{l}\text { 個別疾患の早期発見 · 早期治 } \\
\text { 療 }\end{array}$ & & $\begin{array}{l}\text { 内臓脂肪型肥満に着目した早期介 } \\
\text { 入・行動変容 }\end{array}$ \\
\hline $\begin{array}{l}\text { 内 } \\
\text { 容 }\end{array}$ & $\begin{array}{l}\text { 健診結果の伝達, 理想的な生 } \\
\text { 活習慣に係る一般的な情報提 } \\
\text { 供 }\end{array}$ & & 自己選択と行動変容 \\
\hline $\begin{array}{l}\text { の保 } \\
\text { 対健 } \\
\text { 象指 } \\
\text { 者導 } \\
\end{array}$ & $\begin{array}{l}\text { 健診結果で「要指導」と指摘 } \\
\text { され, 健康教育等の保健事業 } \\
\text { に参加した者 }\end{array}$ & & $\begin{array}{l}\text { 健診受診者全員に対し, 必要度に } \\
\text { 応じ, 階層化された保健指導を提 } \\
\text { 供 }\end{array}$ \\
\hline 方 & $\begin{array}{l}\text { 一時点の健診結果のみに基つ } \\
\text { く画一的な保健指導 }\end{array}$ & \multirow[t]{3}{*}{$\begin{array}{l}\text { 促行 } \\
\text { 委憅 } \\
\text { 手恋 } \\
\text { 法容 } \\
\end{array}$} & $\begin{array}{l}\text { 健診結果の経年変化や将来予測を } \\
\text { 踏まえた保健指導集団の健康課題 } \\
\text { の分析。 } \\
\text { ライフスタイルを考慮した保健指 } \\
\text { 導 }\end{array}$ \\
\hline $\begin{array}{l}\text { 評 } \\
\text { 価 }\end{array}$ & $\begin{array}{l}\text { アウトプット（事業実施量） } \\
\text { 評価。実施回数や参加人数 }\end{array}$ & & $\begin{array}{l}\text { アウトカム (結果) 評価 } \\
\text { 糖尿病等の有病者·予備軍の } 25 \% \\
\text { 減少 }\end{array}$ \\
\hline $\begin{array}{l}\text { 実 } \\
\text { 施 } \\
\text { 主 } \\
\text { 体 }\end{array}$ & 市区町村 & & 医療保健者 \\
\hline 料） & $\begin{array}{l}\text { 厚生労働省 健康居 } \\
\text { 改変 }\end{array}$ & & ラム（確定版）P8一部 \\
\hline
\end{tabular}


選択することとなっており，リスクの高い順から積極的 支援・動機付け支援・情報提供と階層化される。もう一 つの特徵として, 階層化された対象者に対し, 医師・保 健師・管理栄養士等が的確な継続的支援を行い病気にな るリスクを減らし, 生活習慣病の減少という結果を求め られる点である。そのためには，効果的に支援が出来る 管理栄養士を育成し，国民の健康づくりの担い手として 活躍することが求められている。

\section{愛知県の栄養士会の取り組み}

愛知県栄養士会では, 平成 19 年度・ 20 年度に「標準的 な健診・保健指導プログラム」を元に会員対象の特定保 健指導担当者研修会（管理栄養士を対象）を実施し，2 年間で 914 名が修了した。また平成 20 年度において食生 活改善指導担当者研修会（栄養士を対象）も合わせて行 い48名が修了した。平成20年度の愛知県栄養士会会員は 約 2,650 名弱ほどであり会員の36\%程の会員が修了した ことになる。修了者の中から，保健指導に携わる意思の ある者を把握するため登録制とし, 早速, 職場において 保健指導の活動を開始した会員もいる。愛知県でも, 平 成20年度に健保事業活動拠点として「栄養ケアステーシ ヨン」を設置し, ここに特定保健指導依頼を集約し運営 を開始した。栄養ケアステーションに集まった仕事は， 管理栄養士 3 人で 1 グループを作りそのグループ毎に仕 事を配分するシステムを作りあげた。現在 10 以上のグ ループが活動しており, 今後さらに増える予定である。 しかし，「栄養ケアステーション」は出発したばかりで あり, 財政基盤が不十分なため専属の事務員が配置出来 ず，常務理事が兼務しながら統括している。このように， 運営管理システムや関係機関との連携方法, 財源など問 題山積であるが念願であった「栄養ケアステーション」 を立ち上げ運営を開始したことは大きな一歩であると感 じている。今後は, 運用方法や採算性を検討しながら, 地域に打ける栄養専門領域業務の中心的活動拠点を目指 し更なる飛躍を会員一同一丸となって取り組んでいきたい。 愛知県栄養士会病院協議会の取り組み

愛知県では, 健診センターを付設している病院はもと より，新規に増収を期待し特定保健指導に活路を見いだ す病院も現れている。愛知県栄養士会病院協議会として, 特定健診 ·保健指導の活動状況把握のため研修会参加者 151名にアンケートを実施した。

\begin{tabular}{l|r}
\multicolumn{1}{c}{ 表 2 参加者職域内訳 } \\
\hline 行政 & 2 \\
\hline 研究教育 & 1 \\
\hline 地域活動 & 3 \\
\hline 集団健康 & 1 \\
\hline 病院 & 108 \\
\hline 福祉 & 36 \\
\hline 合計 & 151 \\
\hline
\end{tabular}

(1)特定保健指導にあなたは携わってますか

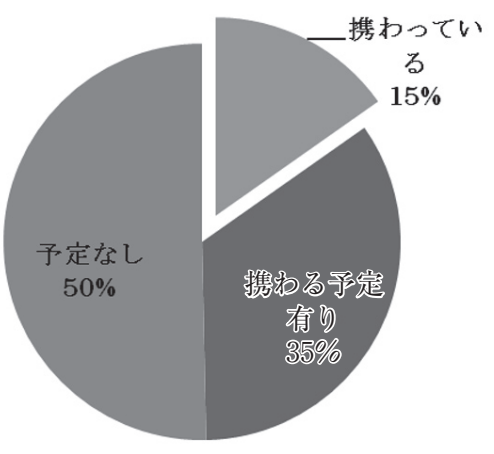

(2)特定保健指導に携わっている方は, 専任ですか兼務ですか

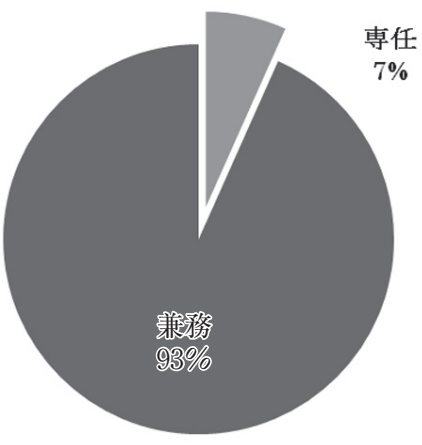

(3)特定保健指導用のソフトは導入 されていますか

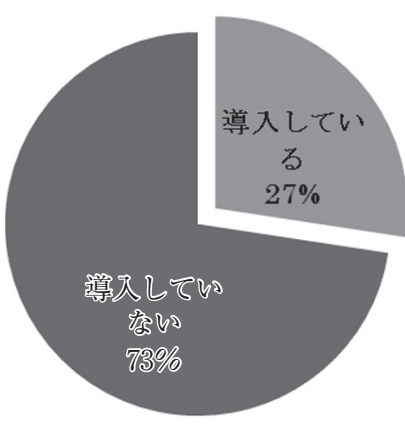

(4)特定保健指導を開始するに当たり， 管理栄養士の増員はありましたか

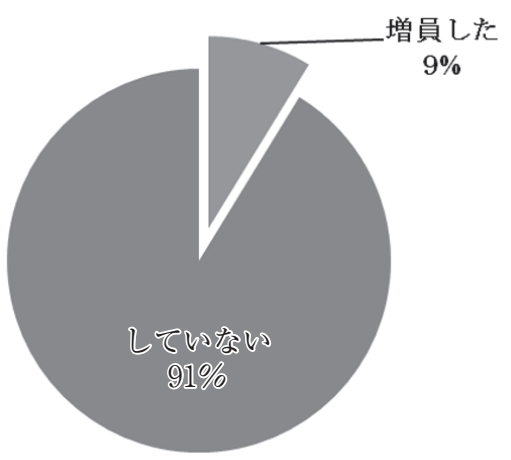

(5)特定保健指導に従事されて困っていることはありますか

○事務や契約に関する用語が分かりづらい

○事務的作業が予想以上に多いため業務量が増加した

○委託側々受託側では, 特定保健指導に対する考え方 にギャップがありその板挟みになること 
○兼務のため, 通常業務と特定保健指導業務の両立が

困難なこと

○保健指導方法や媒体が少ないこと

○院内にて，保健指導体制が整っていないこと

○管理栄養士だけが担当し他のスタッフの協力が少な いこと

○思ったより保健指導対象者が少ないこと。

このアンケートより，まだ始まったばかりであるため 院内での運用方法・スタッフ間での協力体制が確立され ていないことや業務量増加の負担感か強いことがうかが える。どこの施設においても，高価な保健指導用ソフト 購入よりも万歩計や体重測定グラフなどの媒体を使用し 先行投資はせず，既存の媒体を利用している。また，ど この施設からも思ったより保健対象者が少ないなどの問 題点が明らかとなった。

\section{当院の予防医療センターでの特定健診結果より}

当院は，名古屋市港区にある621床の急性期総合病院 である。平均在院日数は15日であり, 名古屋市南部の基 幹病院として位置づけられている。当院には，予防医療 センターが付設されており，医師・看護師・管理栄養 士・検査技師・理学療養士のスタッフにて人間ドックを 始め各種健診を行っている。当院は, 現在, 特定健診は 実施しているが，保健指導はまだ未実施である。しかし， 予防医療センターと栄養管理室が主体となり運用方法の 準備は整っており今後，依頼があれば対応できるシステ ムとなっている。平成20年 4 月より 9 月までに実施した 腹囲測定者 1,068 名の健診結果とアンケートの内容の一 部は以下のとおりである。

\section{(1)男性の腹囲の分布}

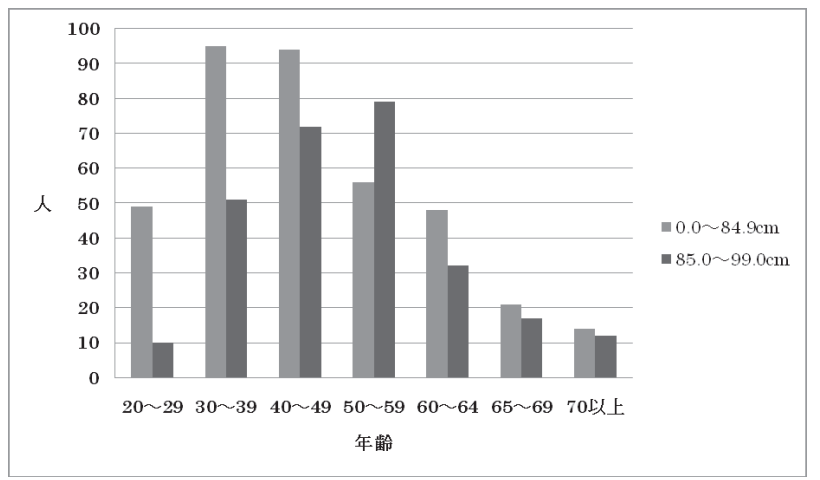

(2)女性の腹囲の分布

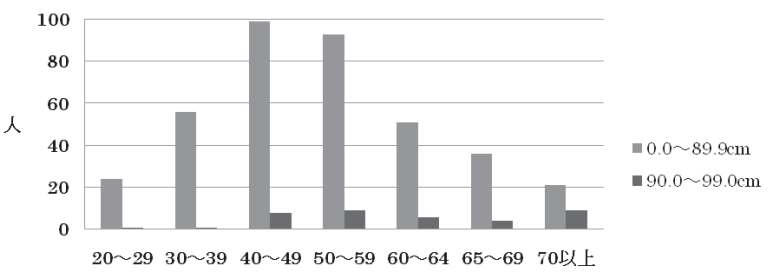

年齢
(3)腹囲測定結果
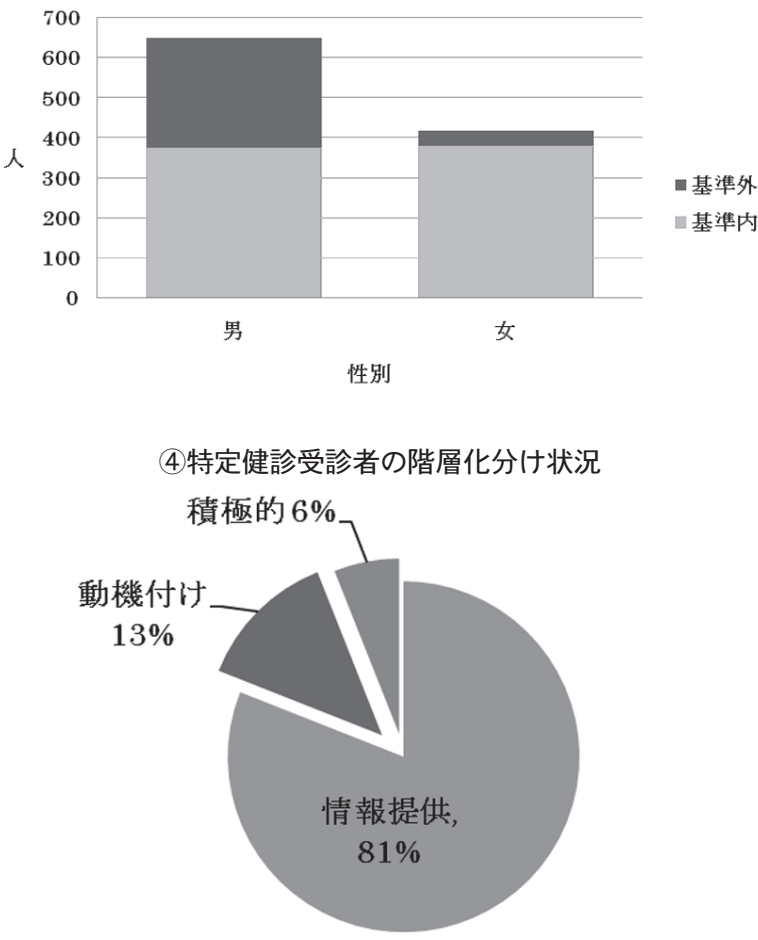

(5)アンケート〜特定保健指導を希望されますか〜

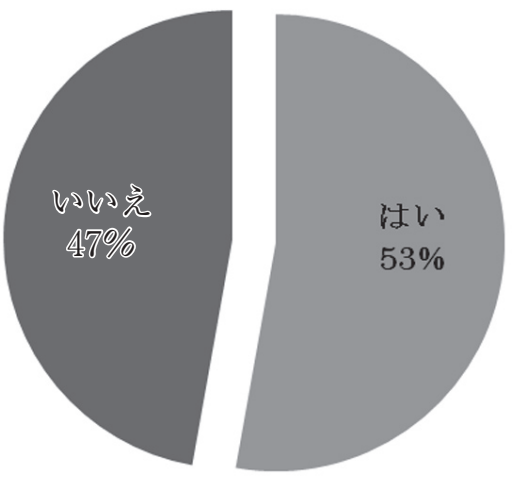

特定健診の現状とまとめ

愛知県栄養士会での活動状況や病院協議会が行ったア ンケート調査, 当院での特定健診結果を合わせて特定健 診 ·保健指導の現状を見てみると健診や階層化分けの段 階までは各区市町村や健診センターにおいて実施されて いるが，その後の保健指導となると動きが鈍いと感じて いる。実際，積極的支援者の保健指導受診は少ないとの 情報をよく耳にしている。まさしく, 病気でない対象者 にリスクを認識させ保健指導を受けるという行動変容を 起こす難しさが浮き彫りとなっている。やはり，保健指 導が全国民に浸透し自ら保健指導を受けようと思わせる ためには，当初は，対象者に働きかけるお世話役が必要 ではないかと感じている。当院のアンケートの中に「保 健指導を希望しますか」という問いに対し, 半数の人は 希望している。しかし，実際に保健指導を受けるという 行動に結びついておらず，各企業・市区町村であれ，誰 かがお世話役に徹し保健指導が当たり前という流れを作 
るためには官民一体となった取り組みが必要ではないか と思う。行動変容を起こさせ結果を出すためには, 指導 者としての個人の研鑚だけでなく栄養士会という組織を 通し管理栄養士の技量・媒体作成能力などを向上させる
必要がある。管理栄養士は各職場において少数ながらも 期待されている職種であるという自負をもとに，知恵を 出し, 工夫を重斌, 実績を作り国民の健康づくりに寄与 しなければならない。

本稿は, 第37回大会における主題講演をあとめたものである。 